\title{
Paralel Flyback Converter sebagai PFC pada Lampu LED menggunakan Fuzzy Type-2
}

\author{
MOH. ZAENAL EFENDI, DEWI KUSUMA WATI, LUCKY PRADIGTA \\ SETIYA RAHARJA
}

Politeknik Elektronika Negeri Surabaya, Indonesia

Email: zen@pens.ac.id

Received 17 Mei 2021 | Revised 8 Juni 2021 | Accepted 10 Juli 2021

\begin{abstract}
ABSTRAK
Peralatan elektronika umumnya memerlukan catu daya berupa sumber tegangan $D C$ yang berasal dari sumber tegangan AC $220 \mathrm{~V}$ yang disearahkan menggunakan penyearah gelombang penuh. Pemasangan filter kapasitor pada sisi output penyearah menyebabkan bentuk gelombang arus masukan terdistorsi sehingga menimbulkan arus harmonisa yang mengakibatkan nilai faktor daya menjadi rendah. Artikel ini membahas mengenai paralel flyback konverter sebagai PFC (Power Factor Correction) pada lampu LED 36 V/60 W menggunakan algoritma fuzzy type-2. Flyback konverter pertama sebagai regulator tegangan DC bekerja dalam kondisi CCM (Continuous Conduction Mode). Flyback konverter kedua sebagai PFC bekerja dalam kondisi DCM (Discontinuous Conduction Mode) sehingga konverter bersifat resistif. Hasil simulasi menunjukkan bahwa paralel flyback konverter dapat memperbaiki faktor daya dari 0.597 menjadi 0.903 dan dapat menjaga tegangan keluaran konstan sebesar $36 V$ menggunakan algoritma fuzzy type-2 serta arus input yang dihasilkan memenuhi standar internasional hamonisa IEC61000-3-2 kelas C.
\end{abstract}

Kata kunci: PFC, flyback konverter, IEC61000-3-2, lampu LED, fuzzy type-2

\begin{abstract}
Electronic equipment generally requires a $D C$ voltage source that comes from a rectified 220 AC voltage source using full-wave rectifier. Installing capacitor filter on the output of rectifier makes the input current waveform becoming distorted that cause harmonic current which results in low power factor value. This article discusses parallel flyback converter as PFC (Power Factor Correction) on $36 \mathrm{~V} / 60$ $W$ LED lamp using fuzzy type-2 algorithm. The first flyback converter as voltage dc regulator works in CCM (Continuous Conduction Mode). The second flyback converter as PFC works in DCM (Discontinuous Conduction Mode) to make the resistive converter. The simulation results shows the parallel flyback converter can improve the power factor from 0.597 to become 0.903 and can maintain a constant output voltage of $36 \mathrm{~V}$ using fuzzy type-2 algorithm and the input current meets the international harmonics standard of IEC61000-3-2 class C.
\end{abstract}

Keywords: PFC, flyback converter, IEC61000-3-2, LED lamp, fuzzy type-2 
Paralel Flyback Converter sebagai PFC pada Lampu LED menggunakan Fuzzy Type-2

\section{PENDAHULUAN}

Dalam sistem tenaga listrik terdapat dua jenis beban listrik yaitu beban linier dan beban nonlinier. Disebut beban linier jika gelombang arus dan gelombang tegangan memiliki bentuk yang sama, sedangkan disebut beban non-linier jika bentuk gelombang arus tidak sama dengan bentuk gelombang tegangannya atau dapat dikatakan bentuk gelombang arus terdistorsi (Pratiwi, dkk, 2020). Salah satu contoh dari beban non-linier yaitu rangkaian penyearah atau rectifier (Pinyol, 2015).

Peralatan-peralatan elektronika biasanya memerlukan catu daya berupa sumber tegangan searah yang berasal dari sumber AC $220 \mathrm{~V}$ yang diserahkan oleh full-wave uncontrolled rectifier dengan filter kapasitor yang nilainya cukup besar untuk mengurangi ripple tegangan. Konsekuensi dari pemasangan nilai kapasitor sebagai filter pada penyearah tersebut dapat menyebabkan bentuk gelombang arus masukan menjadi terdistorsi (non-sinusoida) (Asnil, 2020). Hal ini menyebabkan jumlah harmonisa dalam sistem meningkat dan menghasilkan faktor daya yang rendah (Miret, dkk, 2016).

Standar besar harmonisa untuk suatu sistem yang digunakan oleh beberapa negara yaitu standar IEC61000-3-2. Untuk mengurangi harmonisa tinggi dan memperbaiki faktor daya dari rangkaian penyearah dapat dilakukan dengan beberapa cara (Efendi, dkk, 2013), yaitu: (1) Menambah filter induktor yang cukup besar, namun cara ini kurang disukai karena penyearah menjadi lebih berat dan ukurannya bertambah (bekerja pada frekuensi rendah sekitar 50-60 Hz); (2) Menambah pra-regulator perbaikan faktor daya atau disebut two-stage PFC yang biasanya menggunakan buck converter (Lee dan Chae, 2014), boost converter (Yim, dkk, 2013), dan buck-boost converter (Yadav, 2018).

Two-stage PFC memiliki kekurangan, diantaranya membutuhkan banyak komponen sehingga membutuhkan biaya yang besar, memiliki efisiensi yang rendah, dan memiliki sistem kendali yang kompleks (Lo, dkk, 2014) (Chen, dkk, 2013). Oleh karena itu, untuk mengatasi masalah tersebut, digunakan single-stage PFC. Single-stage PFC memiliki kelebihan seperti konfigurasi yang lebih sederhana sehingga kontrolnya lebih sederhana, efisiensi lebih tinggi, dan biaya lebih rendah (Yadav, 2018) (Poorali dan Adib, 2016). Sekarang ini, banyak rangkaian PFC yang telah dikembangkan. Rangkaian tersebut umumnya merupakan integrasi dari DC-DC konverter (Tseng, dkk, 2018). Design and simulation of a single-stage control strategy for power factor correction based on soft switched flyback converter (Patwardhan, dkk, 2019) dan power factor improvement on LED lamp driver using BIFRED converter telah diusulkan (Efendi, dkk, 2020). Rangkaian PFC bekerja dalam kondisi discontinuous conduction mode (DCM) untuk menghasilkan faktor daya tinggi.

Dalam artikel ini membahas implementasi paralel flyback converter sebagai PFC pada lampu LED menggunakan algoritma fuzzy type-2. Implementasi paralel flyback converter sebagai PFC akan memberikan performa yang lebih baik. Flyback converter pertama bekerja dalam kondisi CCM sebagai regulator tegangan dan flyback converter kedua bekerja dalam kondisi DCM sebagai PFC sehingga konverter bersifat resistif. Jadi, ketika penyearah menyuplai beban resistif maka arus beban yang mengalir ke sumber memiliki bentuk gelombang yang sama menyerupai bentuk gelombang tegangan masukannya dan menyebabkan nilai faktor daya yang dihasilkan mendekati 1 (Pratiwi, dkk, 2020). Algoritma fuzzy type-2 digunakan untuk menjaga tegangan keluaran konverter agar tetap konstan $36 \mathrm{~V}$. Fuzzy type-2 merupakan pengembangan dari fuzzy type-1 (Li, dkk, 2018). Fuzzy type-2 memiliki empat proses utama, yaitu fuzzifikasi, inferensi, tipe reduksi, dan defuzzifikasi (Bounechba, dkk, 2014). Masukan dari fuzzy berupa error dan delta error dengan keluaran berupa duty cycle yang akan digunakan untuk mengatur PWM (Pulse Wide Modulation). Tujuan dari artikel ini

$$
\text { ELKOMIKA - } 939
$$


adalah untuk mendapatkan konfigurasi yang sederhana, tegangan keluaran konstan, biaya rendah, meningkatkan faktor daya dan mengurangi harmonisa sehingga memenuhi standar internasional harmonisa IEC61000-3-2 kelas C (Efendi, dkk, 2020) seperti yang ditunjukkan pada Tabel 1.

Tabel 1. Standar Internasional Harmonisa Kelas C (IEC61000-3-2)

\begin{tabular}{|c|c|}
\hline $\begin{array}{c}\text { Harmonisa } \\
\text { (n) }\end{array}$ & $\begin{array}{c}\text { Arus Harmonisa Maksimum yang } \\
\text { Diijinkan (\% Frekuensi Dasar) }\end{array}$ \\
\hline 3 & $30 *$ power factor \\
\hline 5 & 10 \\
\hline 7 & 7 \\
\hline 9 & 5 \\
\hline $11 \leq \mathrm{n} \leq 39$ & 3 \\
\hline
\end{tabular}

\section{METODOLOGI PENELITIAN}

Blok diagram penggunaan paralel flyback converter sebagai PFC pada lampu LED menggunakan algoritma fuzzy type-2 ditunjukkan pada Gambar 1. Skema rangkaian PFC yang diusulkan secara rinci ditunjukkan pada Gambar 2.

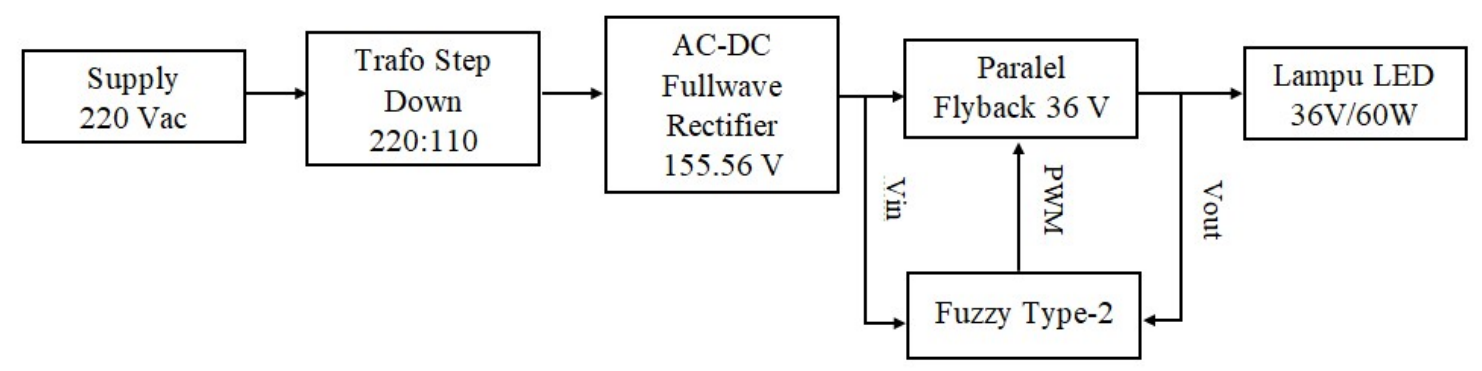

Gambar 1. Blok Diagram Sistem

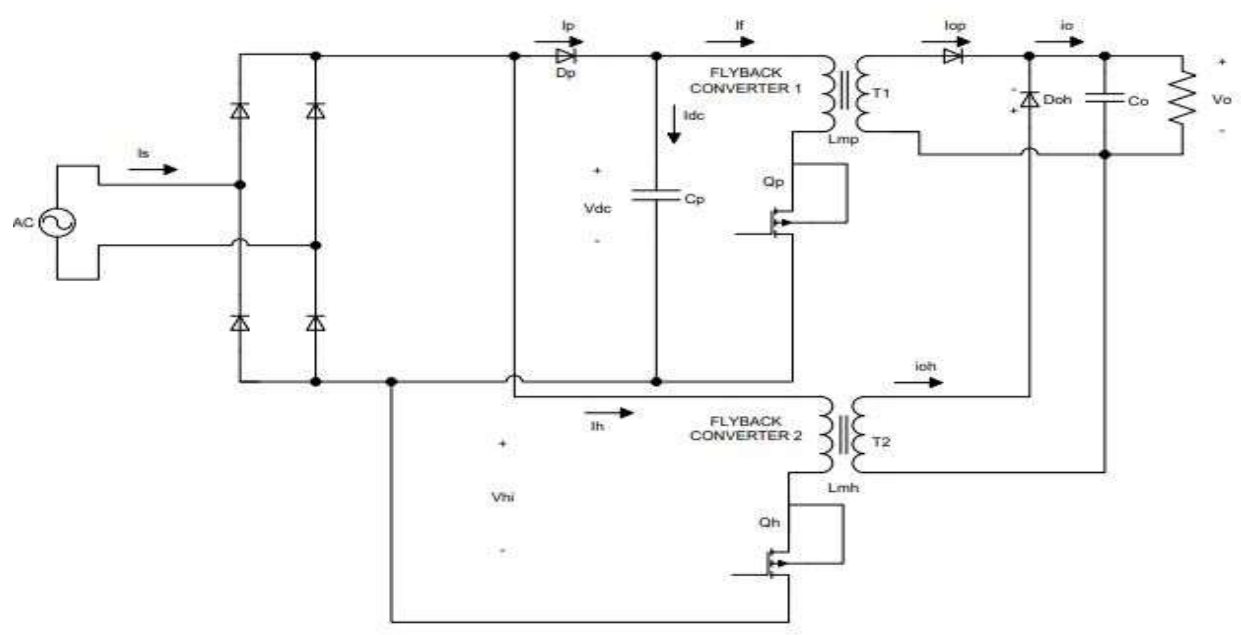

Gambar 2. Skema Rangkaian PFC yang Diusulkan

Pada sistem yang diusulkan ini menggunakan paralel flyback converter, dimana flyback converter pertama berfungsi sebagai regulator tegangan yang beroperasi dalam kondisi CCM 
(Continuous Conduction Mode) dan flyback converter kedua berfungsi sebagai PFC yang beroperasi dalam kondisi DCM (Discontinuous Conduction Mode). Untuk menjaga tegangan keluaran dari flyback converter tetap konstan, maka digunakan algoritma Fuzzy Type-2. Hasil tegangan dari flyback converter ini digunakan untuk mensuplai beban lampu LED sebesar 36 Volt, 60 Watt.

\subsection{Harmonisa}

Beban non-linier pada sistem tenaga listrik menyebabkan munculnya arus/tegangan harmonisa yang frekuensinya merupakan kelipatan dari frekuensi fundamental $(50 / 60 \mathrm{~Hz})$, sehingga mengakibatkan nilai faktor daya yang cukup jelek yang dapat mengakibatkan peralatan yang mendapatkan sumber yang sama menjadi rusak. Berikut ini adalah bentuk persamaan untuk mengetahui nilai faktor daya jika sumber dipengaruhi oleh harmonisa yang ditunjukkan pada Persamaan (1):

$$
\text { power factor }=\frac{V_{r m s} \times I_{1}{ }_{1 r m s} \times \cos \varphi}{V_{r m s} \times I_{1 r m s}}=k \cos \varphi
$$

$\mathrm{k}$ adalah kadar harmonisa suatu sistem yang bernilai satu saat arus sumbernya sinusoidal murni. Untuk menyatakan besarnya kandungan arus harmonisa diperlukan suatu indeks umum yang disebut Total Harmonic Distortion (THD) yang ditunjukkan pada Persamaan (2):

$$
T H D_{i}=\frac{\sqrt{\sum_{h=2}^{\infty} I_{h}^{2}}}{I_{1}} \times 100 \%
$$

Total Harmonic Distortion (THD) merupakan perbandingan nilai rms komponen harmonik terhadap komponen fundamental yang biasanya dinyatakan dalam persen (\%). Untuk menghitung masing-masing harmonisa dapat menggunakan Persamaan (3) berikut ini:

$$
\% \text { arus } k e-n=\frac{\text { arus harmonisa } k e-n}{\text { arus fundamental }} \times 100 \%
$$

\subsection{Flyback Converter}

Flyback converter bekerja dengan konsep yang sama seperti buck-boost converter (Hart, 2011). Transformator yang digunakan adalah transformator non-ideal karena arus tidak dapat mengalir secara simultan pada sisi sekunder akibat dari polaritas transformator yang saling terbalik seperti yang ditunjukkan pada Gambar 3.

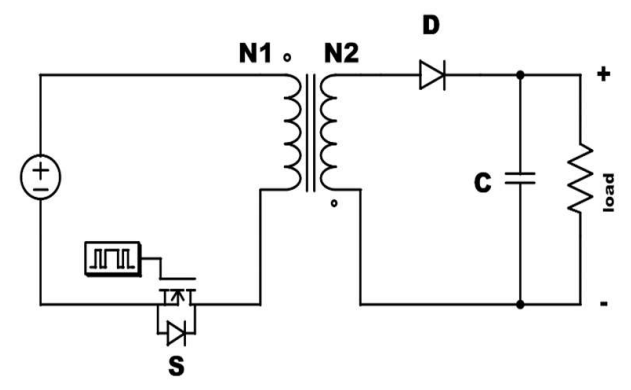

\section{Gambar 3. Rangkaian Flyback Converter}

Flyback converter bekerja saat tegangan masukan $V_{s}$ disimpan pada induktor magnetisasi $\left(L_{m}\right)$ ketika switch on atau tertutup dan menyalurkannya ke beban ketika switch off atau terbuka (Hart, 2011). Flyback converter memiliki tiga kondisi operasi, yaitu continuous conduction mode (CCM), discontinuous conduction mode (DCM), dan critically conduction 
mode (Qi, dkk, 2016). Flyback converter memiliki resistansi masukan $\left(\mathrm{r}_{\mathrm{s}}\right)$ yang dapat dihitung dengan menggunakan Persamaan (4):

$$
r_{s}(t)=\frac{v_{s}(t)}{i_{s}(t)}
$$

Resistansi masukan juga dapat dihitung dengan menggunakan Persamaan (5):

$$
\mathrm{r}_{\mathrm{s}}=\frac{2 \mathrm{~L}_{\mathrm{m}}}{\mathrm{D}^{2} \mathrm{~T}}
$$

Dari Persamaan (5) dapat diketahui bahwa $\mathrm{r}_{\mathrm{s}}$ dipengaruhi oleh induktor magnetisasi $\left(L_{m}\right)$, periode switching $\left(\mathrm{f}_{\mathrm{s}}\right)$, dan duty cycle (D). Flyback converter pertama bekerja pada CCM ketika arus induktor magnetisasi $\left(i_{L_{m}}\right)$ lebih besar dari nol yang ditunjukkan pada Gambar 4(a). Sedangkan DCM ditunjukkan pada Gambar 4(b) dimana arus induktor magnetisasi $\left(i_{L_{m}}\right)$ bernilai nol ketika switch off. Flyback converter kedua bekerja pada DCM dan duty cycle konstan sehingga $r_{s}$ menjadi konstan. Jika $r_{s}$ konstan, maka bentuk gelombang arus masukan ( $\mathrm{t}$ ) mengikuti bentuk gelombang tegangan masukannya, dan flyback converter berfungsi sebagai konverter perbaikan faktor daya.

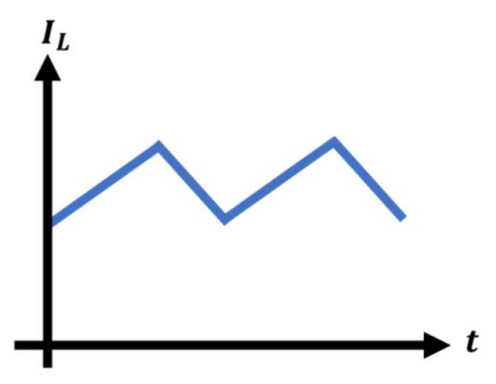

(a)

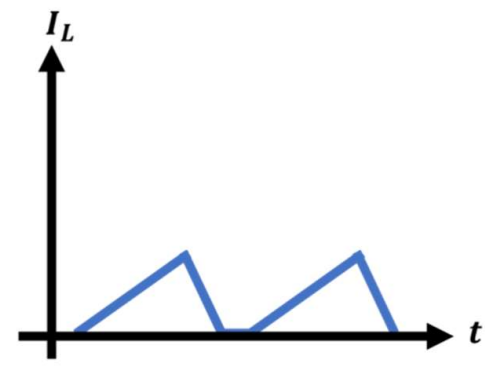

(b)

\section{Gambar 4. Arus Induktor Magnetisasi (a) CCM (b) DCM}

Parameter paralel flyback converter ditunjukkan pada Tabel 2 dan dapat dihitung menggunakan Persamaan (6) sampai Persamaan (8):

$$
\begin{gathered}
V_{o}=V_{S(\max )} \times\left(\frac{D}{1-D}\right) \times\left(\frac{N_{2}}{N_{1}}\right) \\
L_{m}=\frac{\left(V_{S(\min )} \times D_{\max }\right)^{2}}{2 \times P_{\text {in }} \times f_{s} \times K_{R F}} \\
C_{o}=\frac{V_{o} \times D}{R \times \Delta V_{o} \times f}
\end{gathered}
$$


Tabel 2. Parameter Paralel Flyback Converter

\begin{tabular}{|c|c|c|}
\hline \multirow{2}{*}{ Parameter } & \multicolumn{2}{|c|}{ Nilai } \\
\cline { 2 - 3 } & $\begin{array}{c}\text { Flyback Converter } \\
\text { (Regulator tegangan) }\end{array}$ & $\begin{array}{c}\text { Flyback Converter } \\
\text { (Perbaikan Faktor Daya) }\end{array}$ \\
\hline$V_{s(\text { maks })}$ & 155,56 Volt & 155,56 Volt \\
\hline$V_{s(\text { min })}$ & 127,26 Volt & 127,26 Volt \\
\hline$V_{o}$ & 36 Volt & 36 Volt \\
\hline$P_{o}$ & $60 \mathrm{Watt}$ & $60 \mathrm{Watt}$ \\
\hline$f_{s}$ & $40 \mathrm{kHz}$ & $40 \mathrm{kHz}$ \\
\hline$D_{\text {maks }}$ & 0,5 & 0,5 \\
\hline$K_{R F}$ & 0,5 & 1 \\
\hline$N_{p}: N_{s}$ & $110: 26$ & $74: 18$ \\
\hline$L_{m}$ & $1,35 \mathrm{mH}$ & $0,675 \mathrm{mH}$ \\
\hline$C_{o}$ & $2200 \mathrm{uF}$ & $2200 \mathrm{uF}$ \\
\hline
\end{tabular}

\subsection{Fuzzy Type-2}

Fuzzy type-2 merupakan pengembangan dari fuzzy type-1 (Li, dkk, 2018). Algoritma fuzzy type-2 merupakan algoritma yang digunakan untuk mengatasi masalah kebenaran parsial atau ketidakpastian suatu keputusan antara kondisi benar dan salah. Seperti yang ditunjukkan pada Gambar 5, fuzzy type-2 memiliki empat proses utama, yaitu fuzzifikasi, inferensi, tipe reduksi, dan defuzzifikasi (Bounechba, dkk, 2014).

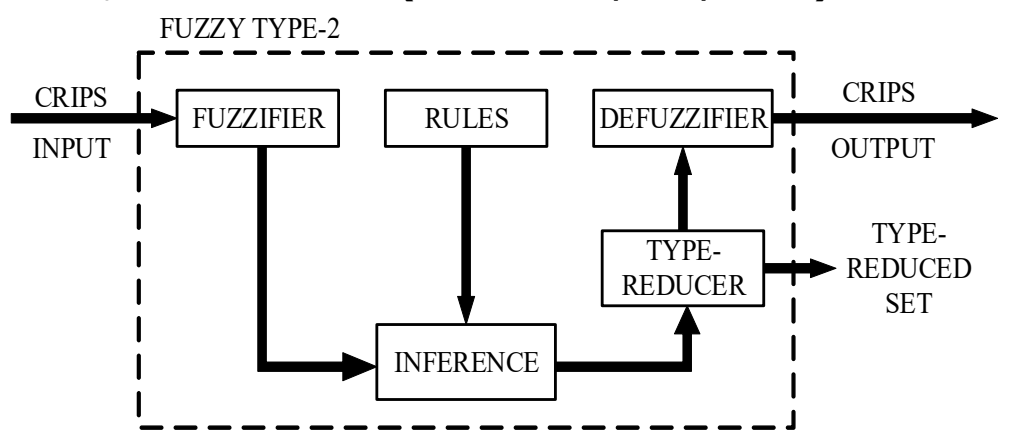

Gambar 5. Sistem Fuzzy Type-2

Fuzzifikasi merupakan proses untuk mengubah masukan dari nilai tegas (crisp input) menjadi derajat keanggotaan pada himpunan-himpunan fuzzy type-2 yang menghasilkan batas-batas dari LMF (Low Membership Function) pada sisi bagian dalam dan UMF (Upper Membership Function) pada sisi bagian luar.

Gambar 6 menunjukkan bahwa fungsi keanggotaan (membership function) yang direncanakan berupa Error, $\Delta E r r o r$, dan Output yang terdiri dari 5 label yaitu NB (Negative Big), NS (Negative Small), Z (Zero), PS (Positive Smal), dan PB (Positive Big). Error adalah selisih antara nilai set point dengan present value, sedangkan $\Delta E r r o r$ adalah selisih antara error saat ini dengan error sebelumnya atau dapat dituliskan menggunakan Persamaan (9) dan Persamaan (10).

$$
\begin{gathered}
\operatorname{Error}_{(n)}=S P_{(n)}-P V_{(n)} \\
\Delta \operatorname{Error}_{(n)}=\operatorname{Error}_{(n)}-\operatorname{Error}_{(n-1)} \\
\text { ELKOMIKA }-943
\end{gathered}
$$




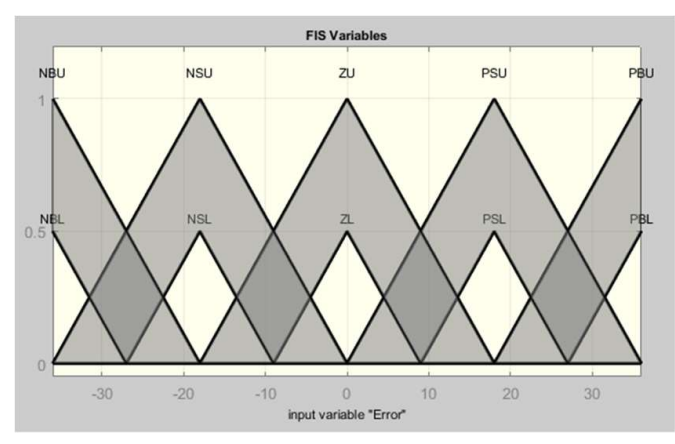

(a)

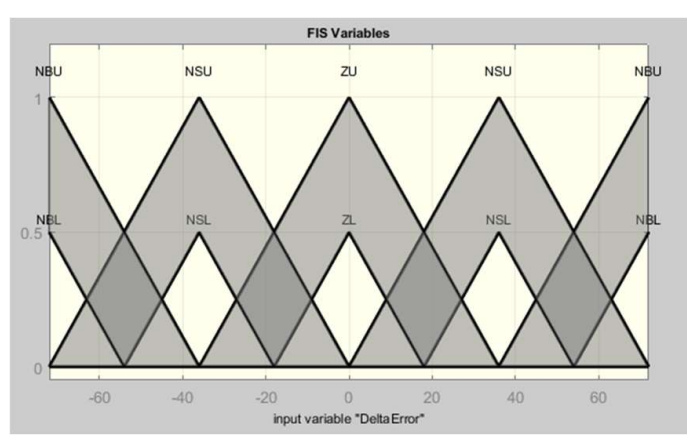

(b)

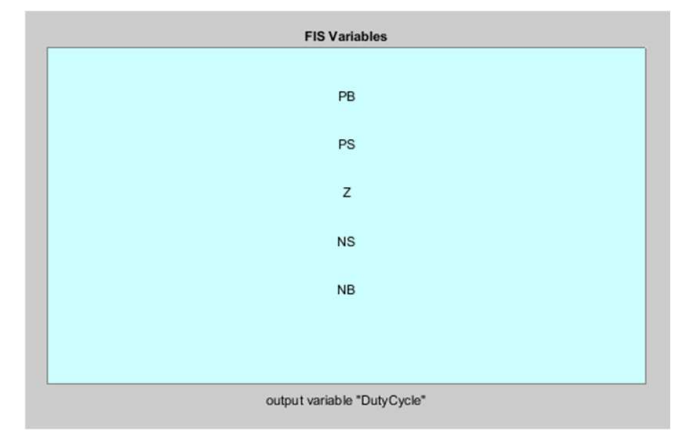

(c)

\section{Gambar 6. Membership Function (a) Error(b) LError (c) Output}

Pada artikel ini, fungsi keanggotaan input menggunakan bentuk segitiga dan bentuk dari fungsi keanggotaan output berupa singleton. Inferensi merupakan proses pengambilan keputusan pada konsep fuzzy. Derajat keanggotaan yang dihasilkan dari proses sebelumnya digabungkan berdasarkan aturan tertentu (rule base). Rule base yang direncanakan memiliki 25 aturan yang berbeda seperti yang ditunjukkan pada Tabel 3. Rule base mengikuti perilaku umum sistem dan ditulis dalam pola label fungsi keanggotaan.

Tabel 3. Rule Base Fuzzy Type-2

\begin{tabular}{|c|c|c|c|c|c|}
\hline Error $\Delta$ & NB & NS & $\mathbf{Z}$ & PS & PB \\
\hline NB & NB & NB & NB & NS & $Z$ \\
\hline NS & NB & NS & NS & $Z$ & $Z$ \\
\hline $\mathbf{Z}$ & NB & NS & Z & Z & PB \\
\hline PS & NS & Z & PS & PS & PB \\
\hline PB & $\mathrm{Z}$ & PS & PB & PB & PB \\
\hline
\end{tabular}

Dari Tabel 3 dapat dilihat bahwa jika kondisi error adalah NB dan $\Delta$ error adalah NB, berarti tegangan output sekarang lebih besar dibandingkan dengan tegangan set point. Oleh karena itu tegangan harus diturunkan lebih besar sehingga untuk rule pertama output-nya adalah NB. Selanjutnya jika kondisi error adalah PB dan $\Delta$ error adalah NB, tegangan output sekarang sama dengan tegangan set point. Oleh karena itu untuk rule selanjutnya outputnya adalah Z. Metode evaluasi rule yang digunakan yaitu inference MIN-MAX dengan mengambil nilai minimum antecedent untuk menentukan rule strength dan nilai maksimum rule strength untuk qonsequent. 
Proses selanjutnya yaitu reduksi tipe. Proses ini hanya dimiliki fuzzy type-2. Disebut sebagai reduksi karena proses ini membawa keluaran dari himpunan fuzzy type-2 yang dihasilkan oleh inferensi menjadi himpunan fuzzy type-1. Terdapat beberapa metode reduksi tipe, diantaranya center of sets, centroid, height, dan modified height (Wang and Mahfouf, 2012). Pada artikel ini menggunakan reduksi tipe dengan metode center of sets.

Setelah proses reduksi tipe, selanjutnya proses defuzzifikasi. Defuzzifikasi merupakan proses mengubah nilai himpunan fuzzy type- 1 hasil dari proses reduksi tipe menjadi nilai tegas yang menjadi hasil keluaran (crisp output). Pada artikel ini metode defuzzifikasi COG (Center of Gravity) atau centroid digunakan pada fungsi keanggotaan dengan output berupa singleton. Menggunakan metode defuzzifikasi COG, keluaran nilai-nilai singleton dikombinasikan menggunakan bobot rata-rata.

\section{HASIL DAN PEMBAHASAN}

Pada artikel ini dilakukan pengujian secara simulasi menggunakan software Power SIMULATOR (PSIM) dengan gambar rangkaian seperti yang ditunjukkan pada Gambar 7. Algoritma fuzzy Type-2 merupakan kendali yang digunakan untuk menjaga tegangan keluaran flyback converter tetap konstan pada tegangan 36 volt menggunakan algoritma yang dimasukkan pada simplified $C$ block.

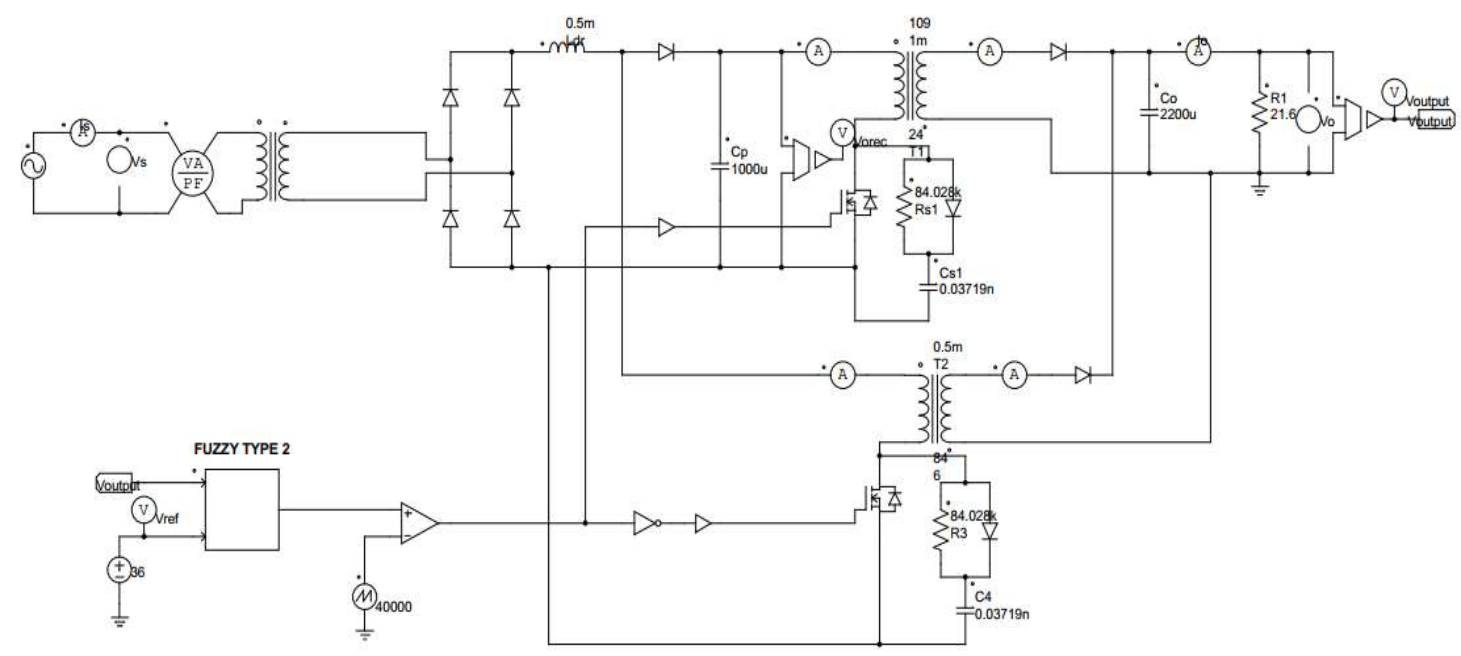

Gambar 7. Rangkaian Simulasi pada PSIM

Pada sistem ini dilakukan dua tahapan pengujian dengan beban lampu LED $36 \mathrm{~V} / 60 \mathrm{~W}$, yaitu pengujian sistem tanpa PFC (paralel flyback converter) dan pengujian sistem dengan PFC (paralel flyback converter). Parameter yang diamati dari pengujian ini adalah tegangan, arus, faktor daya, dan THD-i (harmonisa arus).

\subsection{Hasil Simulasi Pengujian Sistem Tanpa PFC}

Pengujian sistem tanpa PFC dilakukan secara simulasi menggunakan software PSIM. Pengujian ini dilakukan untuk mengetahui nilai faktor daya dan THD-i sistem sebelum adanya perbaikan faktor daya menggunakan paralel flyback converter. Pengujian ini dirangkai menggunakan sumber AC $220 \mathrm{~V}$ yang dihubungkan dengan transformator, kemudian disearahkan menggunakan penyearah gelombang penuh yang terpasang filter kapasitor $1000 \mu \mathrm{F}$. Pemasangan filter kapasitor tersebut bertujuan untuk mengurangi besar 
riak keluaran dari sistem. Dari pengujian ini diperoleh nilai faktor daya sistem tanpa paralel flyback converter sebesar 0,597 dan THD-i sebesar 105,41\%. Gelombang hasil pengujian sistem tanpa PFC ditunjukkan pada Gambar 8.

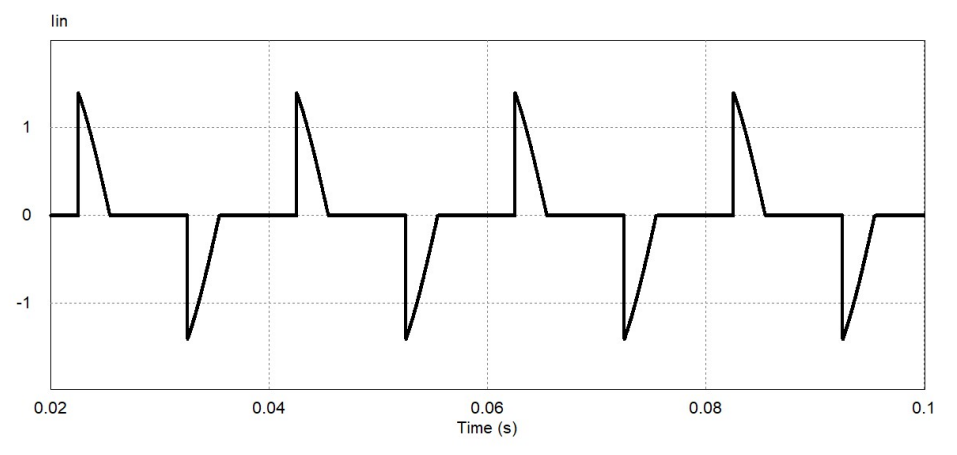

\section{Gambar 8. Gelombang Arus Masukan Hasil Pengujian Sistem Tanpa PFC}

Gambar 8 menunjukkan bentuk gelombang arus masukan yang terdistorsi. Bentuk gelombang arus masukan terdistorsi disebabkan oleh pemasangan filter kapasitor pada sisi keluaran penyearah gelombang penuh yang mengakibatkan arus mengalir saat kapasitor sedang terisi (charge). Hal ini menyebabkan bentuk gelombang menjadi pulsating karena nilai faktor distorsi tidak mendekati 1 tetapi mendekati 0 , sehingga nilai faktor daya rendah.

\subsection{Hasil Simulasi Sistem Dengan PFC}

Pengujian selanjutnya adalah pengujian sistem dengan paralel flyback converter sebagai PFC dengan parameter seperti pada Tabel 2. Berdasarkan Tabel 2 dapat dibuat paralel flyback converter yang berfungsi sebagai PFC dan regulator tegangan dengan menggunakan algoritma fuzzy type-2. Fungsi algoritma fuzzy type-2 pada sistem ini adalah menjaga tegangan keluaran konverter agar tetap konstan 36 Volt.

Pengujian sistem dengan PFC dilakukan secara simulasi menggunakan software PSIM. Pengujian ini dirangkai menggunakan sumber AC $220 \mathrm{~V}$ yang dihubungkan dengan transformator $110 \mathrm{~V}$, kemudian disearahkan menggunakan penyearah gelombang penuh yang terpasang filter kapasitor $1000 \mu \mathrm{F}$. Keluaran penyearah gelombang penuh digunakan sebagai masukan paralel flyback converter yang menghasilkan tegangan keluaran $36 \mathrm{~V}$ sebagai suplai beban lampu LED $36 \mathrm{~V} / 60 \mathrm{~W}$.

Pengujian ini dilakukan untuk mengetahui besar perbaikan faktor daya antara sebelum menggunakan rangkaian paralel flyback converter dan sesudah menggunakan rangkaian paralel flyback converter. Dari pengujian ini diperoleh nilai faktor daya sistem dengan paralel flyback converter sebesar 0,903, sehingga sistem ini dapat dikatakan bekerja dengan baik karena mampu memperbaiki faktor daya dari 0,597 menjadi 0,903. Selain itu, nilai THD-i turun menjadi 25,17\% dari yang sebelumnya 105,41\%. Gambar 9 menunjukkan bentuk gelombang arus masukan. Setelah adanya rangkaian perbaikan faktor daya (paralel flyback converter) bentuk gelombang arus masukan mendekati sinusoidal, sehingga nilai faktor distorsi mendekati 1 dan menghasilkan nilai faktor daya tinggi. 


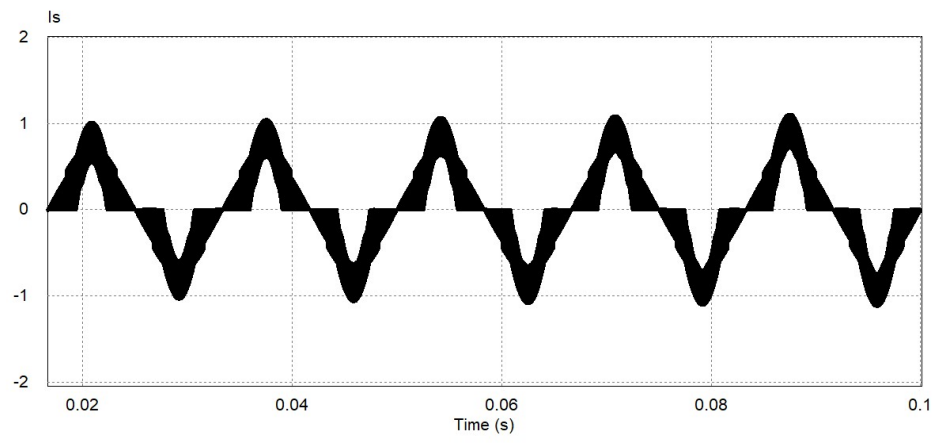

Gambar 9. Gelombang Arus Masukan Hasil Pengujian Sistem Dengan PFC

Gambar 10(a) menunjukkan bentuk gelombang tegangan keluaran dengan nilai $V_{0} 35,96$ Volt dan Gambar 10(b) menunjukkan bentuk gelombang arus keluaran dengan nilai Io 1,66 Ampere. Berdasarkan hasil simulasi sistem dengan paralel flyback converter menggunakan algoritma fuzzy type-2, dapat dilihat bahwa algoritma fuzzy type-2 berhasil mengendalikan tegangan keluaran konverter dengan rata-rata 35,96 Volt dari tegangan setpoint 36 Volt. Sehingga didapatkan nilai error tegangan keluaran sebesar $0,11 \%$.

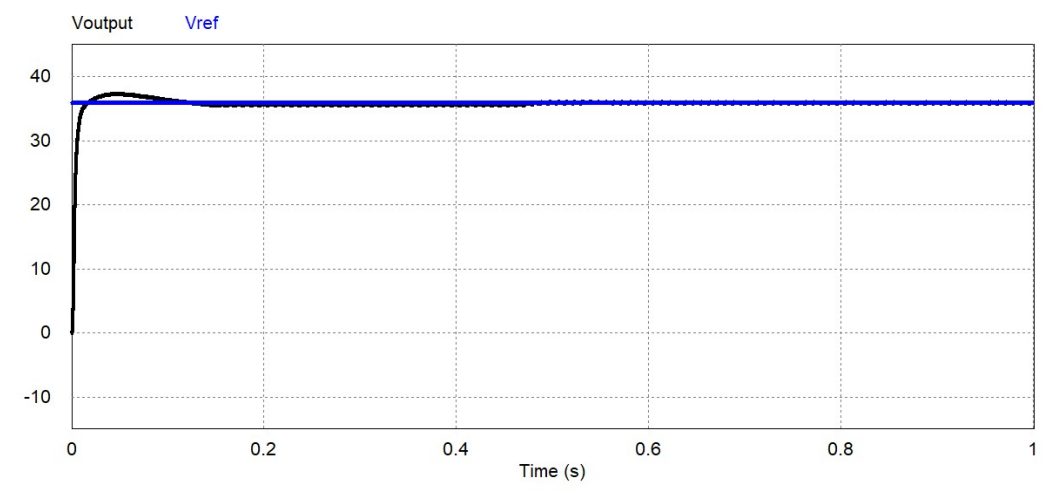

(a)

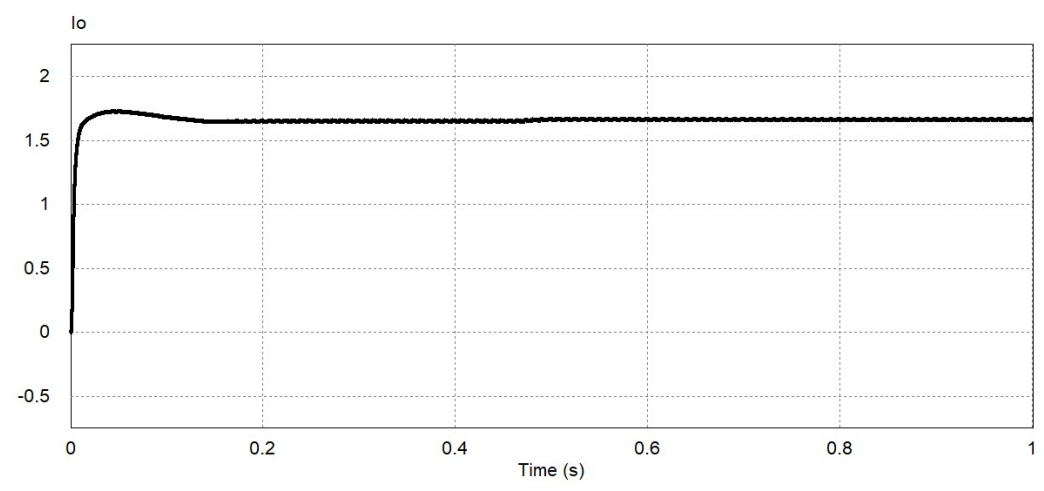

(b)

Gambar 10. Hasil Pengujian Sistem Dengan Paralel Flyback Converter (a) Gelombang Tegangan Keluaran (b) Gelombang Arus Keluaran 


\subsection{Perbandingan Antara Sistem Tanpa PFC dan Sistem Dengan PFC}

Gambar 11 menunjukkan perbandingan antara spektrum harmonisa dalam sistem tanpa PFC dengan spektrum harmonisa dalam sistem dengan PFC.

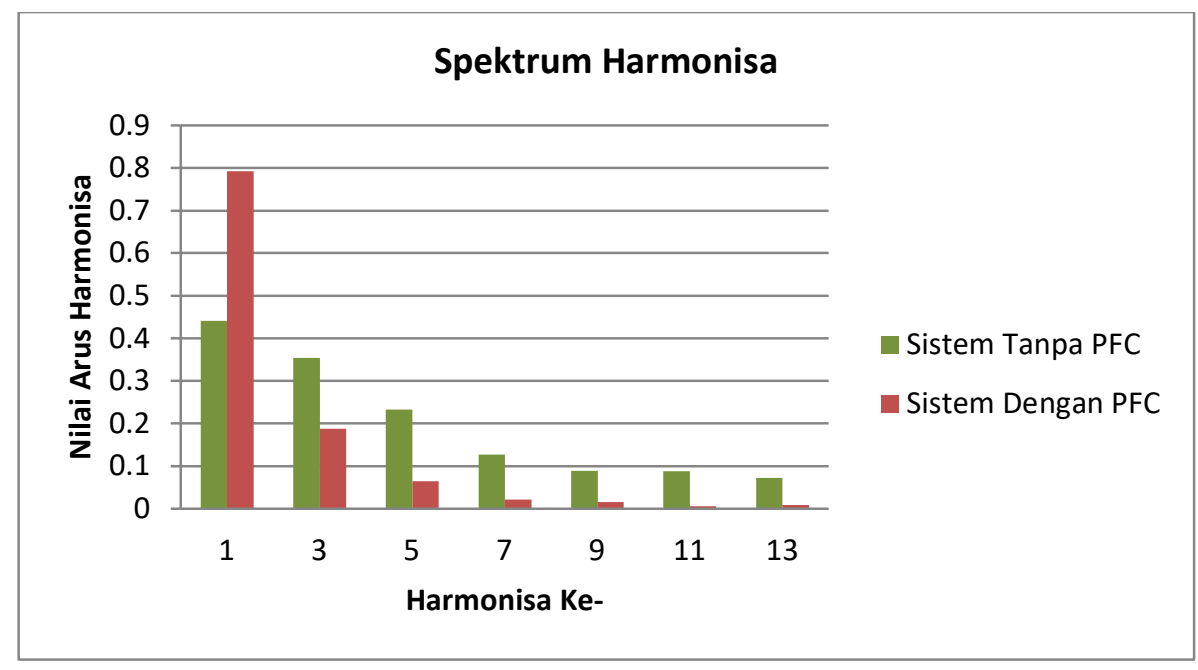

Gambar 11. Spektrum Harmonisa Pada Gelombang Arus Masukan

Berdasarkan Gambar 11 dapat diketahui bahwa dengan memasang rangkaian paralel flyback converter maka spektrum harmonisa yang terdapat pada gelombang arus masukan menjadi rendah (mendekati 0). Hal ini terjadi karena setelah pemasangan rangkaian paralel flyback converter sebagai PFC, bentuk gelombang arus masukan mendekati sinusoidal sehingga nilai faktor distorsi mendekati 1 dan faktor perpindahan mendekati 1 yang menghasilkan nilai faktor daya tinggi. Dari Gambar 11 dapat dilihat bahwa nilai arus harmonisa sistem dengan PFC lebih tinggi dibandingkan nilai arus harmonisa sistem tanpa PFC pada frekuensi fundamental. Hal ini terjadi karena adanya pemasangan rangkaian paralel flyback converter sebagai PFC sehingga mengalami perubahan nilai beban yang mengakibatkan adanya kenaikan arus.

Tabel 3 menunjukkan perbandingan nilai THD-i dan nilai faktor daya antara sebelum dan sesudah pemasangan paralel flyback converter sebagai PFC. Berdasarkan Tabel 3 dapat dilihat bahwa nilai faktor daya yang sebelumnya 0,597 naik menjadi 0,903 dan nilai THD-i yang sebelumnya $105,41 \%$ turun menjadi $25,17 \%$ setelah pemasangan rangkaian PFC.

Tabel 3. THD-i dan Faktor Daya

\begin{tabular}{|c|c|c|}
\hline Parameter & $\begin{array}{c}\text { Sistem Tanpa PFC } \\
\text { (Paralel Flyback Converter) }\end{array}$ & $\begin{array}{c}\text { Sistem Dengan PFC } \\
\text { (Paralel Flyback Converter) }\end{array}$ \\
\hline Faktor Daya & 0,597 & 0,903 \\
\hline THD-i & $105,41 \%$ & $25,17 \%$ \\
\hline
\end{tabular}

Berdasarkan jenis peralatan yang digunakan sesuai standar internasional harmonisa IEC61000-3-2, sistem ini menggunakan klasifikasi beban kelas C. Yang termasuk jenis beban kelas $C$ yaitu peralatan penerangan. Dari penjelasan klasifikasi beban kelas $C$, maka lampu LED $36 \mathrm{~V} / 60 \mathrm{~W}$ yang digunakan pada sistem ini merupakan bagian dari beban kelas C. Tabel 4 menunjukkan perbandingan antara batas arus harmonisa yang ditetapkan oleh IEC610003-2 dan arus harmonisa yang dihasilkan sistem menggunakan paralel flyback converter sebagai PFC. 
Paralel Flyback Converter sebagai PFC pada Lampu LED menggunakan Fuzzy Type-2

Tabel 4. Perbandingan Data Arus Harmonisa Sistem dan Standar Harmonisa IEC61000-3-2 Kelas C

\begin{tabular}{|c|c|c|c|}
\hline $\begin{array}{c}\text { Urutan } \\
\text { Harmonisa Ke- }\end{array}$ & $\begin{array}{c}\text { Nilai Arus } \\
\text { Harmonisa }\end{array}$ & \% Arus & $\begin{array}{c}\text { Prosentase Maksimum } \\
\text { Dari Arus Fundamental } \\
\text { (\%) }\end{array}$ \\
\hline $\mathbf{3}$ & 0,187 & 23,58 & $30 *$ power factor $=30 * 0.903$ \\
\hline $\mathbf{5}$ & 0,064 & 8,07 & 10 \\
\hline $\mathbf{7}$ & 0,021 & 2,65 & 7 \\
\hline $\mathbf{9}$ & 0,015 & 1,89 & 5 \\
\hline $\mathbf{1 1}$ & 0,006 & 0,76 & 3 \\
\hline $\mathbf{1 3}$ & 0,009 & 1,13 & 3 \\
\hline
\end{tabular}

Berdasarkan Tabel 4, dapat diketahui bahwa sistem yang menggunakan rangkaian paralel flyback converter sebagai PFC memiliki nilai arus harmonisa masukan yang lebih rendah dari batas IEC61000-3-2 kelas C. Dari data pada Tabel 4 tersebut, dapat dibuat suatu grafik agar perbandingan terlihat lebih jelas.

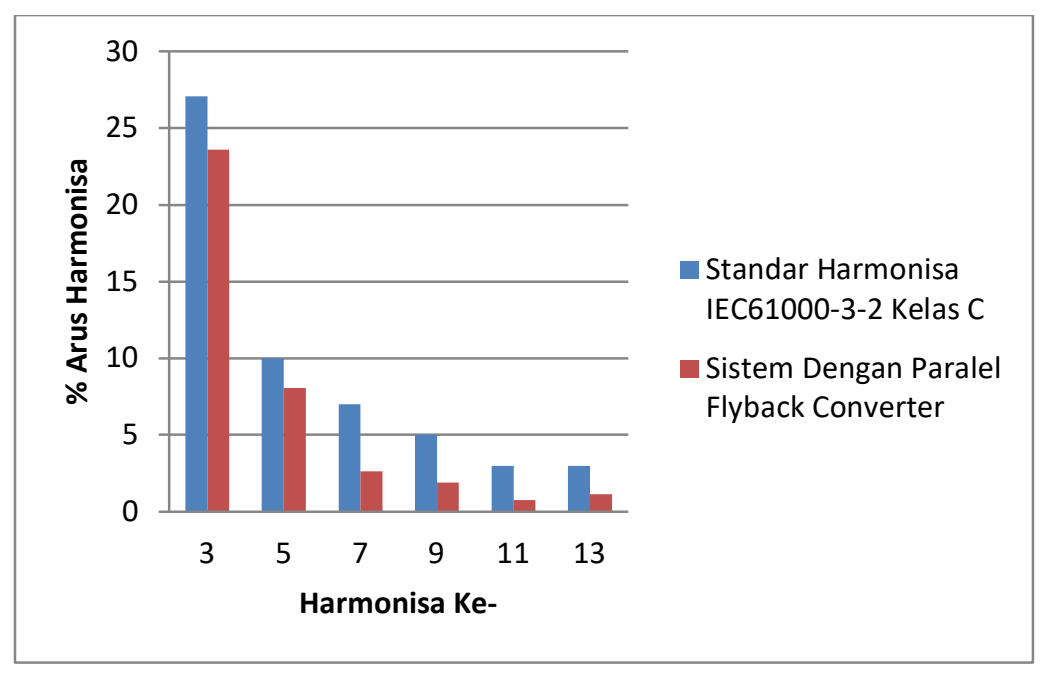

\section{Gambar 12. Grafik Perbandingan Arus Harmonisa Sistem dengan Standar Harmonisa IEC61000-3-2 Kelas C}

Gambar 12 merupakan grafik perbandingan antara batas arus harmonisa kelas C yang ditetapkan oleh IEC61000-3-2 dan arus harmonisa yang dihasilkan sistem menggunakan paralel flyback converter sebagai PFC. Dari grafik tersebut, dapat diketahui bahwa sistem yang diusulkan ini memenuhi standar internasional harmonisa IEC61000-3-2 kelas C karena nilai arus harmonisa masukan yang dihasilkan lebih rendah dari batas IEC61000-3-2 kelas C. Selain itu, sistem yang diusulkan ini dapat memperbaiki atau mereduksi komponen harmonisa sehingga dapat meningkatkan nilai faktor daya.

\section{KESIMPULAN}

Artikel ini telah membahas mengenai penambahan rangkaian PFC pada lampu LED. Konverter yang digunakan sebagai PFC pada sistem ini adalah paralel flyback converter yang bekerja dalam kondisi CCM-DCM. Berdasarkan hasil simulasi menggunakan software PSIM, 
paralel flyback converter dapat meningkatkan nilai faktor daya dari 0,597 menjadi 0,903 dengan nilai THD-i sebesar $25,17 \%$ dan telah memenuhi standar internasional harmonisa IEC61000-3-2 kelas C serta algoritma fuzzy type-2 yang digunakan pada sistem ini dapat menjaga tegangan keluaran konverter konstan 36 Volt. Dalam mendesain dan membuat algoritma fuzzy type 2 harus memperhatikan pembuatan rule base yang menggambarkan perilaku sistem. Berdasarkan penelitian yang telah dilakukan ini, dapat dilakukan penelitian lanjutan dengan menggunakan rangkaian konverter daya lain sebagai PFC sehingga dapat meningkatkan nilai faktor daya dan menurunkan nilai THD-i. Nilai faktor daya yang tinggi dapat mengurangi denda ke PLN karena penggunaan daya reaktif yang rendah. Sementara itu, nilai harmonisa yang rendah dapat memperpanjang masa pakai peralatan elektronika.

\section{DAFTAR RUJUKAN}

Asnil, A. (2020). Unjuk Kerja Filter Pasif dalam Mereduksi Distorsi Gelombang pada AC/DC Konverter. JTEV 6(2), 122-132.

Bounechba, H., Bouzid, A., Nabti, K., Benalla, H. (2014). Comparison of Perturb \& Observe and Fuzzy Logic in Maximum Power Point Tracker for PV Systems. The International Conference on Technologies and Materials for Renewable Energy, Environment and Sustainability - TMREES14, (pp. 677-684).

Chen, X., Jiang, T., Huang, X., Zhang, J. (2013). A High Efficiency Bridgeless Flyback PFC Converter for Adapter Application. IEEE Applied Power Electronics Conference and Exposition - APEC 2013, IEEE, Long Beach, CA, USA, (pp. 1013-1017).

Efendi, Moh.Z., Dwi Murdianto, F., Ardli Fitri, F., Badriyah, L. (2020). Power factor improvement on LED lamp driver using BIFRED converter. TELKOMNIKA 18(1), 571578.

Efendi, Moh.Z., Windarko, N.A., Amir, Moh.F. (2013). Design and Implementation of Battery Charger with Power Factor Correction using Sepic Converter and Full-bridge DC-DC Converter. J. Mechatron. Electr. Power Veh. Technol. 4(2), 75-80.

Hart, D.W. (2011). Power electronics. New York: McGraw-Hil.

Lee, J.-Y., Chae, H.-J. (2014). 6.6-kW Onboard Charger Design Using DCM PFC Converter With Harmonic Modulation Technique and Two-Stage DC/DC Converter. IEEE Trans. Ind. Electron. 61(3), 1243-1252.

Li, J., Yang, L., Fu, X., Chao, F., Qu, Y. (2018). Interval Type-2 TSK+ Fuzzy Inference System. IEEE International Conference on Fuzzy Systems (FUZZ-IEEE), IEEE, Rio de Janeiro, (pp. 1-8).

Lo, Y.-K., Chiu, H.-J., Liu, Y.-C., Lin, C.-Y., Cheng, S.-J., Yang, C. (2014). Analysis and Design of a Push-Pull Single-Stage Flyback Power Factor Corrector. International 
Paralel Flyback Converter sebagai PFC pada Lampu LED menggunakan Fuzzy Type-2

Power Electronics Conference (IPEC-Hiroshima 2014 ECCE-ASIA), IEEE, Hiroshima, Japan, (pp. 2593-2597).

Miret, J., Castilla, M., de Vicuna, L.G., Marti, P., Velasco, M. (2016). Non-Linear Control of a Power-Factor-Correction Rectifier With Fast Dynamic Response. IEEE 25th International Symposium on Industrial Electronics (ISIE), IEEE, Santa Clara, CA, USA, (pp. 504-509).

Patwardhan, A., Usha, A., H.N., P.K., Reddy, N. (2019). Design and Simulation of a Single Stage Control Strategy for Power Factor Correction based on Soft Switched Flyback Converter. IEEE 16th India Council International Conference (INDICON), IEEE, Rajkot, India, (pp. 1-4).

Pinyol, R. (2015). HARMONICS: CAUSES, EFFECTS AND MINIMIZATION, Salicru White Papers, REF. JN004A01 ED, 1-32.

Poorali, B., Adib, E. (2016). Analysis of the Integrated SEPIC-Flyback Converter as a SingleStage Single-Switch Power-Factor-Correction LED Driver. IEEE Trans. Ind. Electron. 63(6), 3562-3570.

Pratiwi, A.A., Efendi, Moh.Z., Murdianto, F.D. (2020). CUK Converter for Power Factor Correction Using Moth Flame Optimization-PI Controller. IOP Conf. Ser.: Materials Science and Engineering 982, (pp. 1-12).

Tseng, S., Huang, P., Wu, D. (2018). Power Factor Corrector with Bridgeless Flyback Converter for DC Loads Applications. Energies 2018, 11, 3096, 1-20.

Qi, W., Jie, W., Lang, B. (2016). Design of Single-Stage Flyback PFC Converter for LED Driver. TELKOMNIKA 14(4), 1263-1268.

Wang, S., Mahfouf, M. (2012). A New Computationally Efficient Mamdani Interval Type-2 Fuzzy Modelling Framework. IEEE International Conference on Fuzzy Systems (FUZZIEEE), IEEE, Brisbane, Australia, (pp. 1-8).

Yadav, A. (2018). A Literature Survey on Power Factor Correction using Boost Converter Rectifier-Cascaded with DC to DC Converter with Multiple Loads. International Journal of Creative Research Thoughts (IJCRT), 6(2), 1178-1185.

Yim, S., Lee, H., Kim, S., Lee, B., Kang, K. (2013). A Behavioral Model of a Two-Stage Average-Current-Mode-Controlled PFC Converter for Dimmable MR16 LED Lamps. International Soc Design Conference (ISOCC), IEEE, Busan, South Korea, (pp. 380383). 